\title{
Acute myocardial infarction in Republic of Srpska
}

\section{DDarko Adžić*, Areta Ognjenović, AAleksandar Zrnić, ○Željka Aćimović, Đorde Jerković}

University Clinical Centre of the Republic of Srpska, Banja Luka, Bosnia and Herzegovina
RECEIVED:

October 17, 2018

ACCEPTED:

November 5, 2018

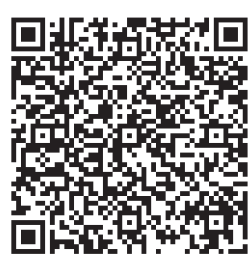

KEYWORDS: acute myocardial infarction, percutaneous coronary intervention. CITATION: Cardiol Croat. 2018;13(11-12):491. | https://doi.org/10.15836/ccar2018.491

*ADDRESS FOR CORRESPONDENCE: Darko Adžić, Univerzitetski klinički centar Republike Srpske, Dvanaest beba, 51000 Banja Luka, Bosnia and Herzegovina. / Phone: +387-51-342-100 / E-mail: tehnicardarko@gmail.com

ORCID: Darko Adžić, https://orcid.org/0000-0001-8976-3343• Areta Ognjenović, https://orcid.org/0000-0002-7676-7780 Aleksandar Zrnić, https://orcid.org/0000-0001-5878-7959 • Željka Aćimović, https://orcid.org/0000-0002-4962-1444 Đorđe Jerković, https://orcid.org/0000-0001-5005-3870

\section{|IIIIIIIIIIIIIIIIIIIIIIIIIIIIIIIIIIIIIIIIIIIIIIIIIIIIIIIIIIIIIIIIIIIIIIIIIIIIIIIIIIIIIIIIIIIIIIIIIIIIIIIIIIIIIIIIIIIIIIIIII}

Acute myocardial infarction (AIM) is a consequence of total interruption of blood flow in coronary arteries. Most often it happens suddenly because of thrombosis which occludes the lumen of coronary artery or some of its side branches. This condition is treated in two ways medications and PCI (percutaneous coronary intervention) $)^{1}$, that is interventional method in which by passing the wire through occluded coronary arteries and ballooning and respectively placing the stent on the spot of thrombosis and reopening the blood vessel. AMI is successfully managed in Republic of Srpska since 2008 and guided by initiative "Stent for life" since 2014. We are covering the 24-hour time, respectively every acute coronary infarction which arrives in "golden hour" time is immediately hospitalized and taken care of in our Cath lab. Over 600 AIMs per year is hospitalized in University Clinical Centre in Banja Luka from all areas of Republic. The fascinating fact is that over 90\% of patients is done by using the radial approach. At the moment, in our Cath lab there are 7 specialists of interventional cardiology, 4 physicians at specialization, 5 medical and 3 x-ray technicians. Our team is educated in world renewed cardiology centers and successfully follows the guidelines of world cardiology association. We are also working on continuity of education and we keep following the latest trends in a world, as for physicians, so for medical and x-ray technicians. 